\title{
From Carlos to Kaepernick and beyond: athletes' right to freedom of expression
}

\author{
Johan Lindholm ${ }^{1}$
}

Published online: 5 December 2017

(C) T.M.C. Asser Instituut 2017

On August 14, 2016, the starting quarterback for the American football team San Francisco 49ers, Colin Kaepernick, made headlines around the world when he remained seated during the singing of the United States' national anthem. Kaepernick explained that he was "not going to stand up to show pride in a flag for a country that oppresses black people and people of color." ${ }^{1}$ Kaepernick's right to make a political statement in this manner was publically supported by the National Football League (NFL), his employer, his coach, and many more. ${ }^{2}$ Others have been less supportive of these kinds of protests, including most prominently American President Donald Trump. ${ }^{3}$

Over the last year, many athletes have joined Kaepernick in protesting in this manner. Outside the United States, this includes the players for the German football club Hertha Berlin who through their actions sought to show their support for diversity and tolerance and against racism and all kinds of discrimination. ${ }^{4}$ Their actions took place in Olympiastadion Berlin where one of sport's perhaps most powerful symbolic statements against racial intolerance occurred 81 years earlier when African-American athlete Jesse Owens won four Olympic gold medals in front of Adolf Hitler.

The actions of Kaepernick and those who have followed his example have brought to the fore not only issues of equality and discrimination but also of athletes' right to freedom of expression. The symbolic action of sitting down or dropping to one knee during the national anthem for the purpose of commenting on or drawing attention to a political issue such as inequality will in many jurisdictions constitute political expression covered by the legal right of freedom of expression, a historically significant and broadly recognized human right. ${ }^{5}$ In the words of the European Court of Human Rights, "[f]ree elections and freedom of expression,

Johan Lindholm

johan.lindholm@umu.se

1 Professor of Law, LL.D, Department of Law, Umeå University, 90187 Umeå, Sweden particularly freedom of political debate, together form the bedrock of any democratic system." 6

Thus, it may seem as if Colin Kaepernick is, as President Obama expressed it, "exercising his constitutional right to make a statement."7 Obviously, athletes enjoy the same freedom of expression as other individuals. It is, however, less obvious whether and to what extent athletes' legally protected freedom of expression extends to making political expressions on the field of play. To what extent do athletes have a legal right to use the spotlight that sport provides to them to make a political expression?

The freedom of expression foremost constitutes a freedom from governmental interference with free speech. The problem with such interference with regard to political expressions such as those discussed here is obvious. While some entities associated with government and public power have reacted negatively to the NFL protests in a way that

\footnotetext{
${ }^{1}$ Wycke S. Colin Kaepernick explains why he sat during national anthem, NFL Media, August 27 2016. http://www.nfl.com/news/ story/0ap3000000691077/article/colin-kaepernick-explains-why-hesat-during-national-anthem. Accessed December 12017. 2 Id.

3 "Wouldn't you love to see one of these NFL owners, when somebody disrespects our flag, to say, 'Get that son of a bitch off the field right now, out, he's fired!'”. Quoted in Graham A, How Trump Turned Kaepernick's Protest Into a Success, The Atlantic, September 25 2017; Freedman S, Politics Has Always Had a Place in Football, New York Times, September 242017.

${ }^{4}$ Frankfurter Allgemeine, Hertha fordert Trump heraus, October 15 2017.

5 See, e.g., Article 19 of the Universal Declaration of Human Rights; Article 10 of the European Convention on Human Rights; Article 10 of the Human Rights Act (United Kingdom); Déclaration des droits de l'homme et du citoyen, Article XI (France).

${ }^{6}$ Bowman v. the United Kingdom, 24839/94, judgment of February 19 1988, para 42. See also Handyside v. the United Kingdom, $5493 / 72$, para 49 ("Freedom of expression constitutes one of the essential foundations of [a democratic] society, one of the basic conditions for its progress and for the development of every man.").

${ }^{7}$ Lutz T. Barack Obama: Kaepernick has right to protest over 'real, legitimate issues', The Guardian, September 52016 (emphasis added).
} 
may have a chilling effect, ${ }^{8}$ the interference with athletes' freedom of expression is more likely to come from employers or sport governing bodies.

The issue of the players' duty to stand for the national anthem is not regulated by the collective bargaining agreement or the NFL rulebook. The NFL game operations manual provides that "[d]uring the National Anthem, players on the field and bench area should stand at attention, face the flag, hold helmets in their left hand, and refrain from talking" but it does not mandate it. ${ }^{9}$ Thus, NFL players' ability to protest in connection with the singing of the national anthem is not actually restricted. However, what if the NFL or another sport league mandated that, athletes must stand at attention during the national anthem. Would the athletes be able to challenge such a rule or a disciplinary action levied against them for violating such a rule on the grounds that it violates their right to freedom of expression? ${ }^{10}$

There are some obvious similarities between Kaepernick's actions and those of Tommie Smith and John Carlos during the 1968 Mexico City Olympic Games. Having placed first and third in the men's 200-m dash, Smith and Carlos stepped on to the podium to receive their medals. During the playing of the national anthem of the United States, the athletes raised their gloved fists in a salute associated with the Black Power movement in racial protest. Smith and Carlos suffered many consequences following their actions, both within and outside the world of sport. ${ }^{11}$ Smith and Carlos violated the IOC's policy of keeping sport apolitical, to the extent that this is possible. ${ }^{12}$ This policy is expressed in Rule 50 of the IOC Charter:

No kind of demonstration or political, religious or racial propaganda is permitted in any Olympic sites, venues or other areas.

It is conceivable that the scope and enforcement of Rule 50 will be tested during the Pyeongchang Winter Olympic Games which are to commence on February 8, 2018. ${ }^{13} \mathrm{~A}$

\footnotetext{
8 In addition to President Trump's statement quoted above, see, e.g., Kahn (2017) regarding statements made by police unions.

9 Reprinted in Sports Illustrated. Here's What NFL Rules Say About Standing for the National Anthem, September 25 2017. https://www. si.com/nfl/2017/09/25/does-nfl-require-players-stand-nationalanthem. Accessed December 12017.

10 With regard specifically to Kaepernick's situation, some of these questions may be answered as part of his action against the NFL and the teams based on collusion. Demand for arbitration, October 15 2017. http://a.espncdn.com/pdf/2017/1015/KaepernickGrievance_r. pdf. Accessed December 12017.

${ }^{11}$ For a comparison of the two events, see Rorke and Copeland (2017).

12 See Thiel et al. (2016).

13 See Wharton D. U.S. athletes will face strict rule against protests at Winter Olympics, Los Angeles Times, September 25 2017; Maese R. U.S. Olympians face political balancing act ahead of next year's Winter Games, Washington Post, September 252017.
}

disciplinary action taken against a protesting athlete during the Olympic Games would be reviewable (and likely reviewed) by the ad hoc division of the Court of Arbitration for Sport (CAS) established for the Games. ${ }^{14}$ The CAS is a Swiss arbitration court with its seat in Lausanne. ${ }^{15}$ As such, a CAS decision regarding a disciplinary action against an athlete exercising his or her freedom of expression-whether in connection with the Olympics or not-can be challenged in Swiss courts for being incompatible with public policy. ${ }^{16}$ This concept covers fundamental legal principles, including certain basic rights and freedoms. ${ }^{17}$

Moreover, signatory states of the European Convention of Human Rights, including Switzerland, can be brought before the European Court of Human Rights (ECtHR) for failure to protect individuals' right to freedom of expression under the Convention against encroachments by private entities. The ECtHR has previously held that this right extends to the workplace and includes this positive obligation for states to protect individuals from being fired for exercising their freedom of expression. ${ }^{18}$ An athlete that is fired or disciplined for a political expression could likely argue that a signatory state must protect them in a similar way. The likelihood of this actually occurring is illustrated by the fact that the ECtHR currently has three cases on its docket concerning whether Switzerland has failed to protect athletes' procedural rights. ${ }^{19}$

This legal framework ought to be considered when sport governing bodies and dispute resolution bodies decide whether and how to discipline athletes making political expressions. The circumstances in the individual case and the relative weight of the interests of the athlete and the sport governing body must be considered and balanced against each other. For example, the interests motivating a restriction carry more weight when the athlete's expression was made during a competition or in another situation where the athlete acts as a representative of a team or a nation. ${ }^{20}$ By comparison, it

\footnotetext{
${ }^{14}$ Rule 61 of the Olympic Charter.

15 Rule S1 of the Statutes of ICAS and CAS.

16 Article 190 of the Swiss Federal Statute on Private International Law.

17 See, e.g., SFT 138 III 322, 327-332, paras 4.1-4.3.

${ }^{18}$ Fuentes Bobo v. Spain, 39293/98, judgment of 29 February 2000, para 38.

${ }^{19}$ Bakker v. Switzerland, 7198/07; Mutu v. Switzerland, 40575/10; Pechstein v. Switzerland, 67474/10.

${ }^{20}$ Relatedly, with regard to the freedom of religion, the Court of Justice of the European Union recently concluded that "the desire to display ... a policy of political, philosophical or religious neutrality must be considered legitimate" and is capable of justifying restricting what employees may wear when working. C-157/125, Achbita \& Centrum voor gelijkheid van kansen en voor racismebestrijding $v$. G4S Secure Solutions NV, ECLI:EU:C:2017:203, paras 37-40.
} 
carries less weight when the expression was made outside the immediate context of sport and in a "private capacity". The fact that Rule 50 covers the entire period of the Games and applies not only to the Olympic site but also to "other areas" is relevant in this regard. The severity of the punishment and its proportionality to the harm of the interest motivating the restriction is also highly relevant. ${ }^{21}$ While this must be determined on a case-by-case basis, a lifetime ban, on the extreme end, would almost certainly be considered disproportional. ${ }^{22}$

\section{References}

Kahn R (2017) Three first amendment puzzles raised by the police union response to speech criticizing police conduct in Ferguson and New York City. Ala Civ Rights Civ Lib Law Rev 8:163-182

Kurlantzick L (2010) John Rocker and employee discipline for speech. Marquette Sports Law Rev 11:185-194

Rorke T, Copeland A (2017) Athletic disobedience: providing a context for analysis of Colin Kaepernick's protest. Fair Play Revista de Filosofía, Ética y Derecho del Deporte 10:85-107

Thiel A, Villanova A, Toms M, Friis Thing L, Dolan P (2016) Can sport be 'un-political'? Eur J Sport Soc 13(4):253-255

${ }^{21}$ Cf. SFT 138 III 322, 330-331, para 4.3.4. See also, e.g., Kurlantzick (2010).

${ }^{22}$ Cf. SFT 138 III 322, 331-332, para 4.3.5. 